Удк 339. 922 /. 923: 061. ЄС

A. В. Чужиков,

к. е.н., дочент кафедри європейсъкої економіки і бізнесу,

АВНЗ "Київський начіональний економічний університет імені Вадима Гетьмана"

ORCID ID: 0000-0002-0312-1655

DOI: $10.32702 / 2306-6814.2020 .4 .28$

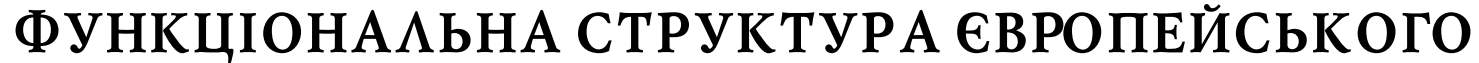 МЕАІЙНОГО РИНКУ
}

\author{
A. Chuzhykov, \\ $\mathrm{PhD}$ in Economics, associate professor of European Economy and Business \\ Department of Kyiv National Economic University named after Vadym Hetman
}

\section{FUNCTIONAL STRUCTURE OF THE EUROPEAN MEDIA MARKET}

Статтю присвячено дослідженню особливостей сучасного медійного ринку Європейського Союзу, їхнім структурних характеристикам та фундаментальним змінам, що відбулися в глобальному і європейському медійному середовищах. Приділено особливу увагу сценаріям розвитку майбутнього телебачення Європи та обгрунтовано значущість функціонування у ньому нових моделей продукування медійних товарів і послуг: "універсальний супермаркет", "контект ендшпілей", "платформа", "хмарне телебачення", "медійні хаби". Підкреслено, що майбутню структуру європейського ринку визначатиме консолідований вплив зазначених інститутів, збереження авторських прав та рівень конкуренції, європейського медійного виробництва.

Проаналізовано ринок платного телебачення, відео та рекламу на прикладі п'яти країн-лідерів, які засвідчують значні зміни, що відбуватимуться впродовж $2020-2030$ рр. Зокрема акцентовано увагу на зростаючій питомій вазі американських брендів в європейському теле-, радіо просторі.

This article is devoted to the study of the features of the modern European Union media market, their structural characteristics and fundamental changes that have taken place in the global and European media environments. Particular attention is paid to the scenarios for the development of the future television of Europe and the importance of the functioning of new models of production of media goods and services: "universal supermarket", "endgame context", "platform", "cloud television", "media hubs". It is emphasized that the future structure of the European market will be determined by the consolidated influence of these institutions, the preservation of copyright and the level of competition, the European media production.

The current European Union media market is heavily influenced by sectoral and content transformation, driven by rapid changes in the global information environment. The main drivers of this kind of shift are: processes of formation of tiered boards of form, economic, social and political interests arising from the collaboration of technological trends; taxonomic diffusion of community media market regulation, which includes direct and covert support from a producer who works in an important sector of common (project participants) interests; commercialization of the media industry and a proprietary way of copyright protection; growing digitization of media technologies and increased competition in the European information space of media companies from the United States, but already China, most recently from the Russian Federation and some Arab countries.

The level of service delivery, operational and strategic management should be considered as a fundamentally new approach. The use of virtually unlimited storage, great opportunities for its use of new approaches in search operations. The pay-TV, video and advertising market is analyzed with the help of five leading countries, which show significant changes that will take place in the period 2020-2030. So now it requires a deeper and more thorough analysis, as well as the use of new identification approaches, which will significantly increase the likelihood of European media market forecasts.

Ключові слова: медіа, медійне середовище, ЄС, регулювання, медійні хаби, платформа, ринок, хмарні технології, Європейська аудіовізуальна обсерваторія.

Key words: media, media environment, EU, regulation, media hubs, platform, market, cloud technologies, European Audiovisual Observatory.

\section{ПОСТАНОВКА ПРОБАЕМИ}

Швидка цифровізація глобального інформаційного середовища внесла суттєві корективи в розвиток медійних ринків, їхніх секторів, контентів та регуляторів.
Традиційні лінійні аналітичні підходи до ідентифікацій європейського медійного середовища вже не давали вичерпних відповідей на модерні виклики континентального соціуму. Відтак зросла реальна потреба в іденти- 
фрікації тих нелінійних змін, які б пояснили динаміку, тренди та інтенсивність фундаментальних секторальних зрушень, що вирують у сучасній глобальній економіці. Водночас відзначається, що чимало дослідників позитивно оцінюють вплив регуляторної системи ЄС на сучасне медійне виробництво, однак аналіз існуючого зараз ринку далеко назавжди дозволяє оцінити масштаби подальшої медійної експансії на цей континент, який тривалий час залишався авангардним у цілому світі. Визначення особливостей функціональної структури ринку Євросоюзу та виокремлення в ньому нових композиційних елементів $€$ важним напрямом сучасних міжнародних економічних досліджень.

\section{АНА $\Lambda$ I3 ОСТАНHIX АОС $А$ IАЖЕН І ПУБ АІКАЦІЙ}

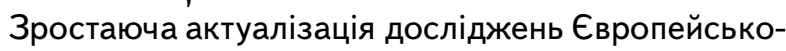
го медійного ринку породила в своїй основі цілу низку тих нових наукових спостережень, котрі напряму відносились до з'ясування в економічній науці особливостей конкурентного середовища ( Н. Ахрем, А. Гріфрфімс, T. Bale, J. Howkins), а також до визначення ролі і значущості медійних компаній в ньому. Також мали місце численні фокусування ідей нового менеджменту в системі продукування і продажу медійних продуктів (L. Kung, L. Mitchell). До кола найбільш відомих дослідників із зазначеної проблематики слід віднести J. Lemke, який першим розробив модель критичного аналізу нових медіа, а також A. Prat, котрому вдалося грунтовно вивчити особливості нових медійних кластерів у Лондоні. Водночас поза увагою науковців залишається проблема прогнозування розвитку і модернізації медійних ринків, їхнього фрункціоналу та платфрормових трендів.

\section{META CTATTI}

Полягає у системному дослідженні європейського медійного ринку в процесі його модернізації, секторальної трансорормації та загострення конкуренції в межах європейського інорормаційному середовища.

\section{ВИКААА ОСНОВНОГО MATEPIA $\Lambda$ Y}

Доволі великі успіхи у розвиткові глобальної медійної сорери, що мали місце упродовж останніх чверть століття внесли суттєві корективи до нового розуміння ролі і значущості ЗМІ, а також їхньої функціональної структури, основою чого стало розуміння, з одного боку, об'єктивних процесів технологізації інорормаційної сорери, включаючи діджиталізацію, проте з другого - значну соціальну, правову, комерційну та емоційну трансформації, наслідком чого стало фрормування так званої третьої (медійної) влади та зростання потенційної можливості маніпулювання свідомістю глобального у т. ч. європейського соціуму. Не виключенням, з огляду на це, став Європейський Союз, котрий за допомогою своїх численних інституцій та апробованої на національних рівнях нормативних баз досяг доволі значних успіхів у процесі просування ідеї свободи мислення, права на об'єктивну інформацію, а також незалежність журналістів. Утім, на привеликий жаль ані в сучасному $Є С$, ані в світі загалом поки що не можна го- ворити про повну гармонізацію відносин у медійному середовищі i, як, красномовно показує європейський досвід, навіть описану вище демократичну європейську модель не може вважатися ідеальною. Утім, слід зауважити, що в сучасному середовищі, медійних суперечностей та зловживань існує чимало. Приміром, доволі масштабне дослідження, котре було проведене F. Sulehria в Індії і Пакістані виявило доволі високий рівень корупції в їхніх медіа, а також недодержання авторських прав у цих країнах [1].

Утім, заявлені вище застереження не обмежуються лише цим регіоном планети, адже на проблему забезпечення прав власності в інформаційному середовищі звертають увагу й в ЄС, зокрема експерти Європейської аудіовізуальної обсерваторії (ЕАО). Зауважимо, що це відбувається тоді, коли йдеться, як зазначають G. Fontaine, D. Kevin [2], про діяльність пан'європейських TV - груп, котрі забезпечують функціонування платного телебачення, яке становить в ЄС, за згадуваними вище авторами, близько 50 \% усього ефрірного часу (2016). Заслуговує на увагу також доволі таки грунтовна праця P. Dunnet [3] з його вдалою, на наш погляд, спробою провести секторальне і географрічне розмежування телевізійної індустрії, у т. ч. на рівні держав ЄС. Тим не менше перелічені вище підходи не можна абсолютизувати, адже визначити функціональну структуру європейського медійного ринку можна також, за допомогою великомаштабних системних досліджень, приміром таких, як "Media in Europe" [4] в межах якого не так давно був проведений глибокий аналіз рекламної сегментації ринку та динаміки нового, до речі доволі валідного сучасного індикатора CAGR, який використовують в процесі розрахунку ефективності того чи іншого виду бізнесу. І медійний, не є при цьому виключенням.

Водночас наявними трендами дослідження особливостей медійного ринку може слугувати дослідження діджиталізації європейських медіа, як це зробив R. Rooke [5] та їхньої європеїзації, начому наполягає A. Harcont [6], котрий виокремлює горизонтальні і вертикальні аспекти цього важливого процесу контингентної конвергенції. 3 нових авторських позицій підходять до розуміння сучасних медійних тенденцій в Європейському Союзі D. Doukas, P. Syrpis [7]. Для них надзвичайного значення набуває дослідження ступеню взаємодії між законодавчою і юридичною владою, натомість комерційний аспект діяльності медіа досліджений авторами недостатньо.

Слід додати також, що для проведення сучасного прогнозування необхідно декілька важливих усвідомлень, котрі відомі світові дослідники Дж. О'Конор та І. Макдермотт називають дотично до медіа системним мисленням (зауважимо, що в оригіналі назва їхньої спільної праці звучить, як "The art of systems thinking. Essential skills for creativity and problem solving"). 3aзначені вище автори запропонували декілька важливих алгоритмів прийняття рішень: цикл навчання, що охоплює: рішення дії у світі $\rightarrow$ усвідомлення зворотнього зв'язку і результати дій $\rightarrow$ різниця між дійсним і бажаним (мета навчання) $\rightarrow$ нові рішення [8, с. 121], розширення світогляду, котре базується на пізнавальному інтересі і охоплює: ментальну модель $\rightarrow$ перспективу $\rightarrow$ 


\title{
Платформа правовласника
}

\author{
ВТРАЧАННЯ \\ PIЗIIOMAIIITIIOCTI
}

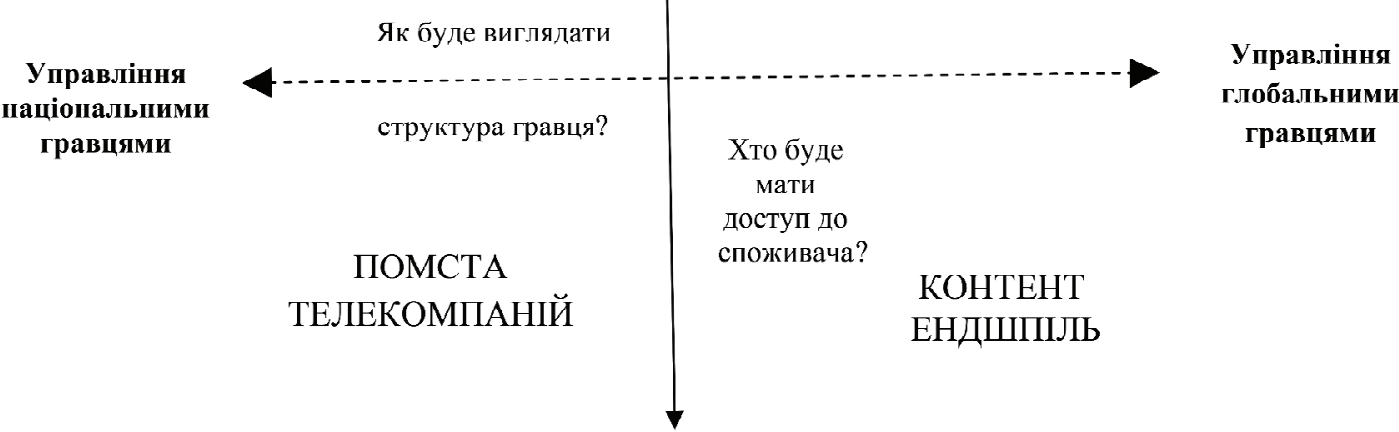

Контент правовласника

\section{Рис. 1. Оглядовий сценарій майбутнього TV та відео на 2030 за розрахунками аналітичної компанії Deloitte}

Джерело: [9, р. 8].

збагачену перспективу $\rightarrow$ ширшу ментальну модель [8, с. 134]. Утім, доволі симптоматичною виглядає системна модель, котра здобула доволі епатажну назву "дорога в пекло: наміри і звинувачення", яка складається зі стимулів (провина), роздратування, зворотнього зв'язку і відповідної лінії поведінки, яка, і на цьому наголошують дослідники, може зазнавати суттєвих змін упродовж короткого часового лагу [8, с. 153]. Утім, біхевіористичні підходи, котрі домінують у сучасній глобальній економіці дозволяють спроектувати нову (змінену) поведінку людей - на перспективу, проте не дозволяють iï абстрагувати, адже медійний ринок наповнений не лише споживачами, а й виробниками, які, з одного боку намагаються догодити смакам споживачів, з другого вони ж ці смаки й фрормують, спираючись при цьому на доволі великий арсенал механізмів і інструментів сучасної психології. Внаслідок цього можна оперувати як традиційним розрахунковим апаратом, на чому наполягають економісти, так і незвичним для економіки, але традиційним для маркетології психологічним, адже сприйняття побаченого на телеекрані і прочитаного в газеті, або в журналі може зазнавати стрімких змін на індивідуальному рівні під впливом глобальних емоційних та інформаційних потоків, котрі також мають свої ціннісні характеристики та споживачі орієнтації. Проте їня недооцінка може зробити складні економетричні розрахунки абсурдними, адже конче важливим для науковця, як раніше, так і зараз слід вважати виокремлення конкретних трендів подальшого розвитку. 3 огляду на вищесказане, слід звернути увагу на доволі важливе дослідження аналітичної компанії Deloitte "The future of the TV and video landscape by 2020", у межах якого й було визначено сценарні тренди двох важливих контентів розвитку (рис. 1).

Пропонована графрічна модель доволічітко віддзеркалює характер, структуру і, що дуже важливо, роль тих фундаментальних змін, що мали місце в глобальному медійному середовищі. Зрозуміло, що саме вони мають бути чітко ідентифіковані в межах не лише ЄС, а й Європи у цілому. Можна погодитись з розробниками пропонованого сценарію щодо фрормування двох надзвичайно важливих викликів: хто й у який спосіб буде мати доступ до споживача, а також як виглядатиме так звана структура медійного гравця, адже переважна більшість передач буде транслюватися через соціальні мережі, а відтак можна прогнозувати цілком ймовірне існування платфрорми правовласників, важливою складовою якої стане контент, інколи затребуваний, інколи - ні. Модель суттєво відрізнятиметься з огляду на реакцію споживачів, адже, з одного боку, існуватиме "універсальний супермаркет", який задовольнятиме усім смакам i уподобанням споживачів, сукупний (також можна запропонувати термін - глобальний) попит, з другого визначатимуть контентні пріоритети, які неодмінно вестимуть до втрачання інтелектуальної різноманітності та потуранню смакам обивателів. Відповідно до цього зазнає змін й так зване елітарне кіно, фрінансова основа виробництва якого може бути зведена нанівець, адже зникнуть бажаючі інвестувати в нього. Наслідками подібного роду зрушень може стати так зване формування ендшпілю, тобто умовної завершальної скарбниці всього, що має попит, а також можливої помсти значної кількості телекомпаній (багатонаціональної змови), вплив яких на глобальний (європейський) простір не визначатиметься лише попитом на рекламу і розважальні програми та "мильні опери".

Не менш важливим в індентифікації особливостей медійного середовища Європи завжди вважалося оцінювання ємності ринку, яке традиційно (до недавнього Брексіту) оцінювалось з врахуванням обсягів відповідних ринків п'яти найбільших країн ЄС (Німеччина, Франція, Великобританія, Італія, Іспанія). Проведене ще у 2010 році "International Television Expert Group" дослідження дозволило встановити тенденцію щодо так званої Web-міграції та розвитку рівня платних послуг (рис. 2). 


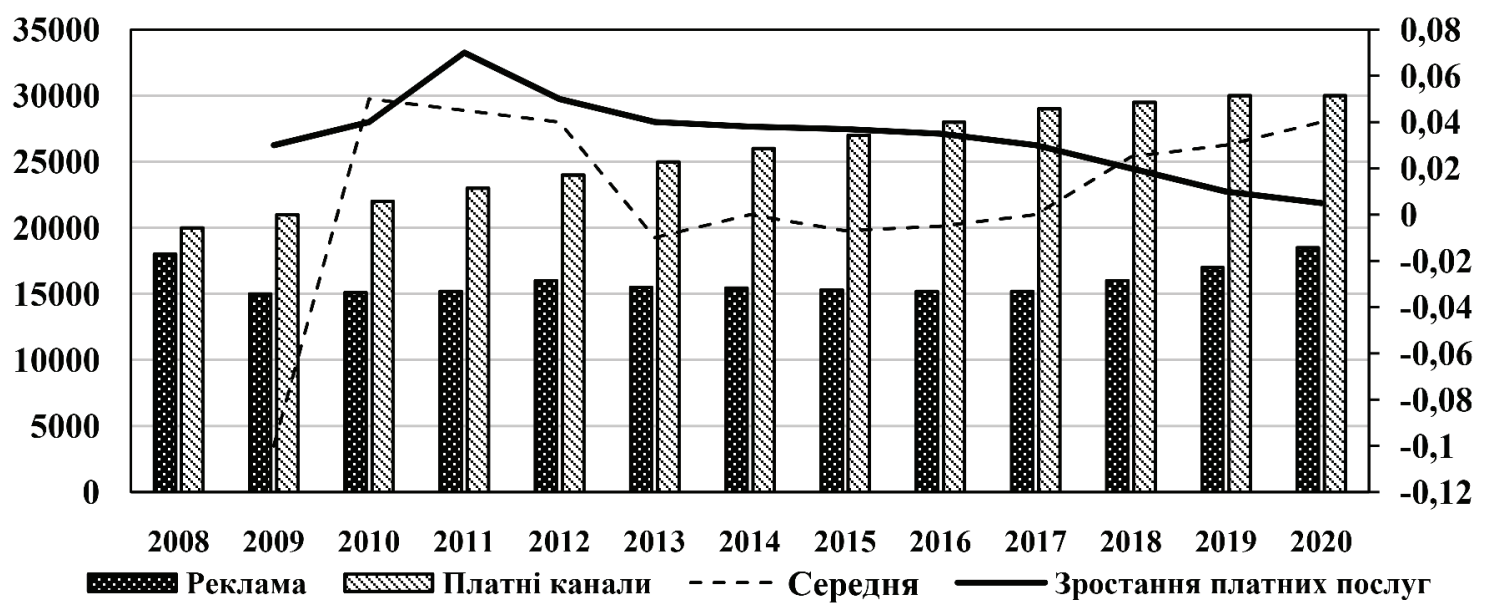

Рис. 2. Ринок платного телебачення, відео та реклами п'яти найбільшх країн $€ С$ (Німеччина, Франція, Великобританія, Іспанія), 2008-2020 рр., за World International Television Expert Group, млрд. євро

Примітка. Advertising (реклама), Рау (платне TV), Раy services growth (зростання рівня платних послуг), а також результюючий вектор.

Джерело: [10].

Як випливає із рисунку, ринок телебачення (маються на увазі платні телеканали та виготовлені відео), тяжіє до розширення, проте надзвичайно важливим для розуміння фінансових механізмів $є$ той факт, що доходи від реклами загалом знижуються, натомість платне телебачення повільно зростає рік від року, що є достатньо показовим. Доволі відчутним для ринку є також зростання рівня платних послуг, котре, як випливає з графіку, має негативну тенденцію. Основними причинами таких трендів, на нашу думку, є таке:

- посилення індивідуалізації сприйняття телепрограм, відео та інших медійних продуктів;

- розширення технологічних можливостей щодо демонстрування улюблених програм у зручний для споживача час та у визначеному ним форматі;

- зростання полінгвістичних тенденцій та можливостей транскордонного співробітництва;

- регулювання пропорційності (реклама /не реклама) під час трансляції передач, програм, фрільмів, анімацій;

- більш високий рівень доступності медійних продуктів та їхнє комбінування (TV + газета, TV + Інтернет тощо).

Однією з найважливіших особливостей сучасних медіа слід вважати нові моделі комунікацій, що формується у сучасному світі. Нерідко їх називають ще й платорормами, котрі базуються, за К. Келлі, на принципах дематеріалізації та децентралізації [11, с. 125], але, з другого боку, численні цифрові компанії все частіше використовують так звані хмарні технології, що формуються як мультиінфоормаційні Web - документи за допомогою гіперпосилань даних [11, с. 126]. Ці новоутворення доволі швидко стимулюватимуть створення так званих інформаційних колоній, тобто з мільйонів об'єднаних комп'ютерів, котрі містять все, що має відноситись до медіа. Такі великі хмари уособлюють собою Google та Facebook. Водночас слід констатувати, що чимало так званих хмар мають комерційний характер (IBM, Oracle, Cloud, Smart Cloud тощо) і свої ціни визначають у прейскурантах. Утім, всі добре розуміють, що

майбутнє цифрових технологій полягатиме в коінтеграції хмар (приєднання до чогось вже наявного), їхньому селектуванні та подальшій комерціалізації прийнятої на зберігання інформації. Безперечно, що під дію

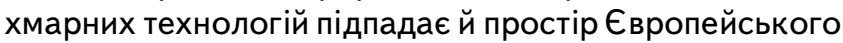
Союзу. До цього, на нашу думку, ведуть декілька важливих трендів, про що піде мова нижче.

Формування численних медійних платформ креативних медіа стало останнім часом надзвичайно важливим завданням для національних і наднаціональних економік, натомість виокремлення секторальних і країнових складників в їхніх межах залишатиметься важливим контентом хмарних технологій і хмарних складів інформації, емоцій, а також багатьох інших продуктів медіаіндустрії. Природно, що гіперконцентрація такого виробництва іїхнє споживання віддзеркалює важливі тенденції локалізації (в сфері медіа - це локалізація версій), що природним чином призводить до формування відповідних скупчень цільових медійних сервісів. На думку експертів Audiovisual Media in Europe, такими високоефективними просторовими формами зосередження медійного бізнесу може слугувати створення хабів, найбільшим з яких слід вважати Панн'європейський, тобто хаб Великобританії, котрий станом на поч. 2018 р. охоплював 638 телевізійних платних каналів, у той час як у Франції їх налічувалось 78, а у Німеччині іБолгарії лише по 25 [12, с. 41]. Слід також зазначити, що суттєва підтримка з боку медіа, окремих видів кіно і телепродуктів значною мірою позначилася на обсягах продукування. Так, якщо у 2007 році в країнах $Є С$ вироблялося 1422 фільми, то в 2017 році їхня кількість зросла до 2123 $[13$, р. 7]. Водночас на компанії країн - лідерів (Великобританія, Німеччина, Франція, Італія) припадало 53,6\% продукованих фільмів. Доволі новою тенденцією європейського медійного ринку стало співпродюсерство 3 боку окремих невеликих держав, котрі попри невелику площу та чисельність населення беруть активну участь у цьому виробництві. У якості доказу слід навести той фракт, що така держава, як Люксембург мала свою частку у європейському випуску фільмів - 53\%, натомість пи- 


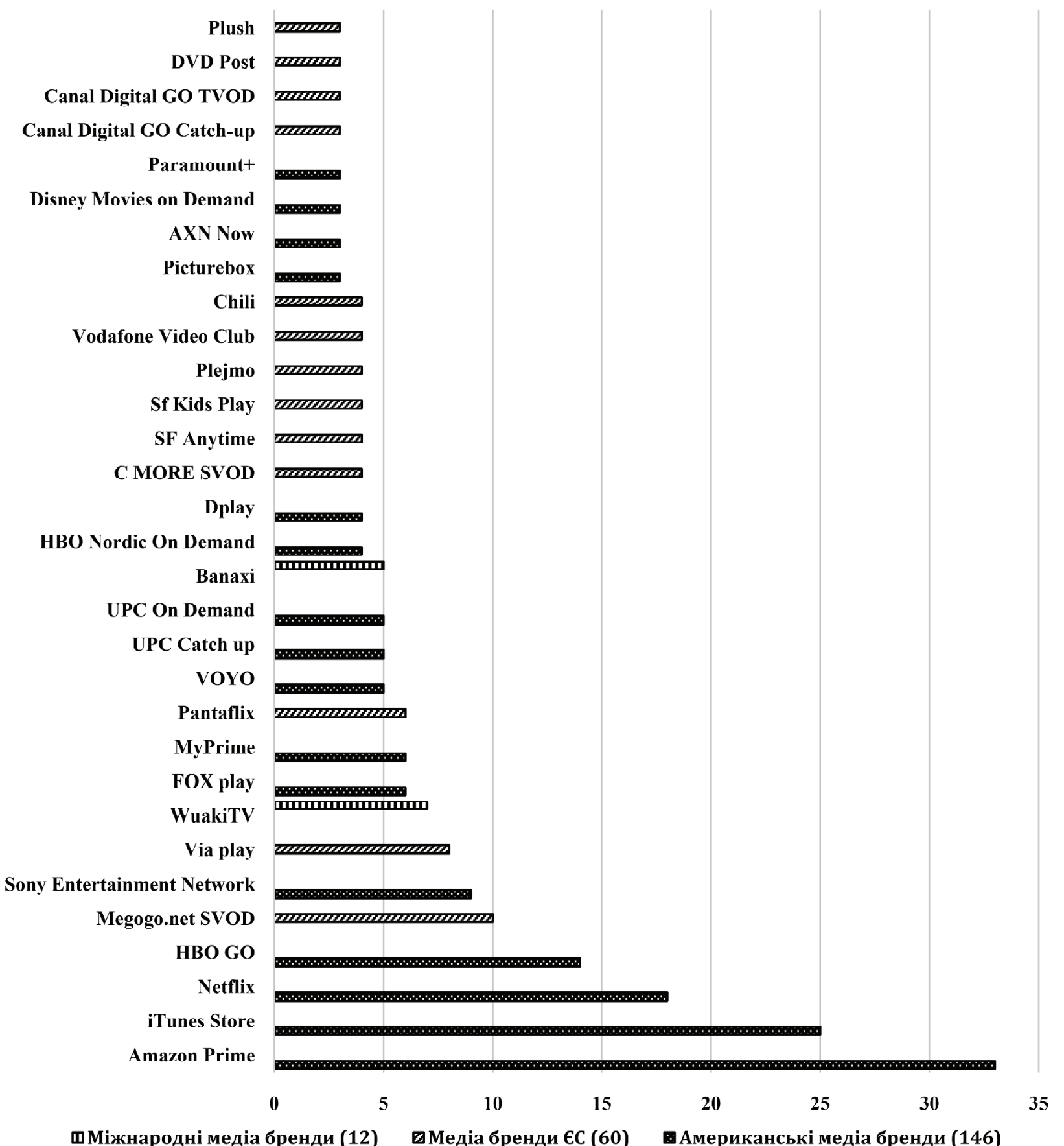

Рис. 3. Топ брендів, платних послуг компаній, що діють в ЄС - 28 за кількістю локалізованих сервісів, 2017 р.

Джерело: European Audiovisual Observatory/ MAVISE database [12].

тома вага сусідньої Бельгії є ще більшою - 56\% [13, р. 7]. Утім, окремі нові числові дані, що характеризують стан європейського ринку визначають не лише динаміку розвитку ринку, а й до цього ще й приналежність компаній (рис. 3 і 4).

Наведені вище рисунки дозволяють зробити певні висновки щодо подальших змін на європейському ринку телевізійних послуг, які можна звести до наступного:

- по-перше, попри всю декларовану доступність телевізійних, відео та інших медійних продуктів тяжіння споживачів до отримання платних послуг в $€ C €$ домінуючим, адже саме воно визначає очікування насе- лення щодо їхнього розуміння привабливості /непривабливості того що пропонує "офріційне телебачення", попит на продукцію якого продовжує падати як у державах спільноти, так і за ії межами (наприклад в Україні);

- по-друге, компанії США пропонують значно більшу кількість локалізованих сервісів аніж власники європейських брендів, що доволі красномовно говорить про те, чия саме ринкова влада має домінуюче значення;

- по-третє, не зважаючи на зростаючий у цьому, рівень інтернаціоналізації (насамперед у контентній сорері) питома вага міжнародних брендів не $є$ такою, що 


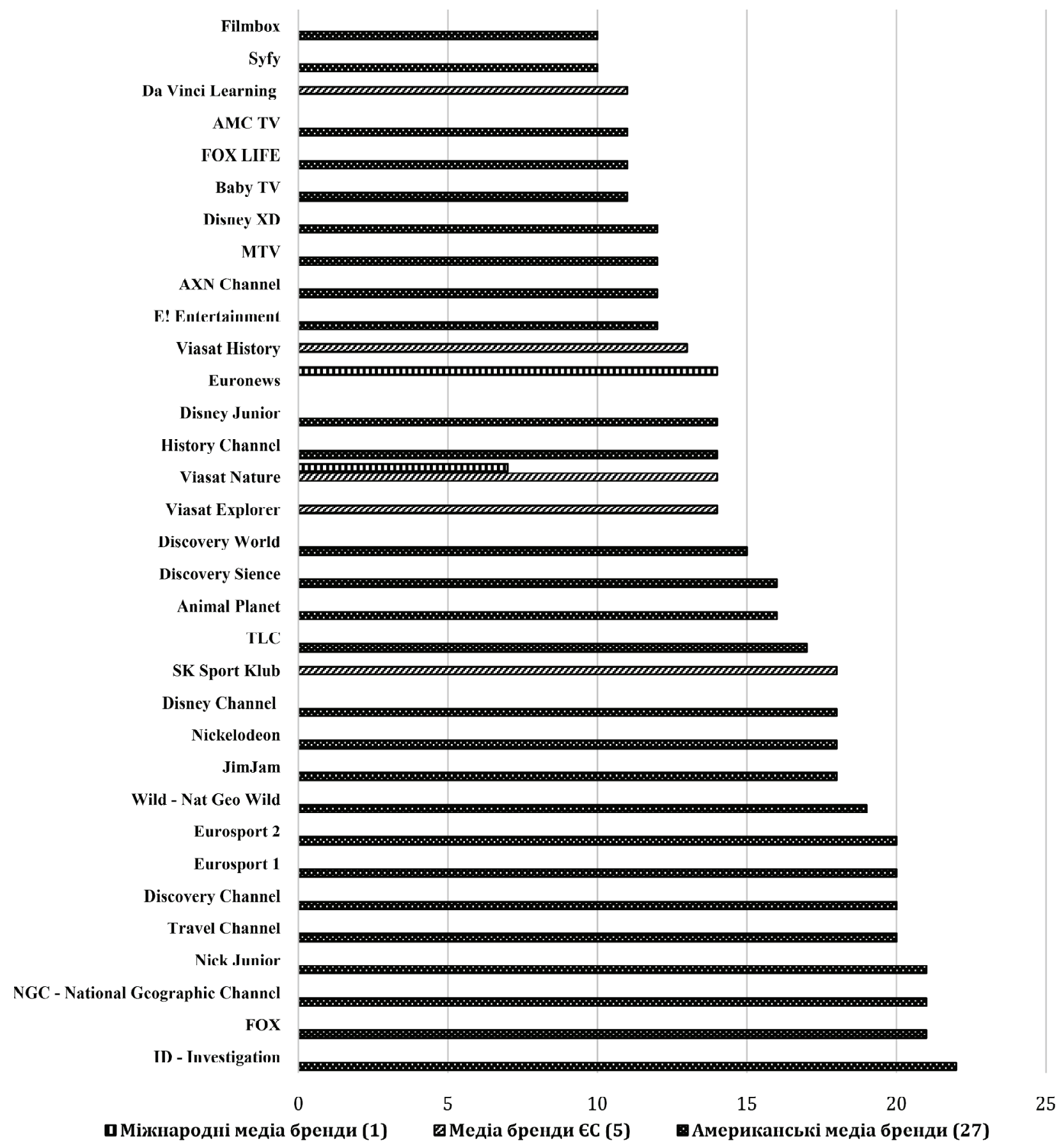

Рис. 4. Tоп брендів TV каналів ЄC - 28 за кількістю локалізованих сервісів, 2017 р.

Джерело: European Audiovisual Observatory / MAVISE database [12].

виглядає захмарною, адже у першому випадку - це лише дві компанії, а в другому одна - Euronews.

3 наведеного вище випливає, що розвиток сучасного медійного ринку Європейського Союзу є складним поліструктурним механізмом трансплаторорменної взаємодії відповідного бізнесу та наднаціональної регуляторної системи держав-учасниць, що $є$ альтернативною до попереднього етапу розвитку моделлю, в основі якої лежить оцифрування існуючого і перспективного культурного надбання, яке за допомогою хмарних технологій може стати доступним (оплатним /безплатним) для усіх користувачів. Принципово новим підходом слід вважати рівень надання послуг, оперативний і стратегічний менеджмент. Використання практично безмежної пам'яті, великі можливості її застосування нових підходів у пошукових операціях.

Слід зазначити, що прогнозовані тренди мають неабияке значення не лише для Європейського Союзу, а й для усього континенту. Раніше ми зауважували, що такі країни як Грузія і Україна (A. Chuzhykov, 2018) мають суттєво переглянути свій медійний і технологічний контент [14, р. 25], однак у глобальному сенсі цим державам для забезпечення свого технологічного лідерства треба зробити ще доволі багато.

\section{ВИСНОВКИ}

Сучасний медійний ринок Європейського Союзу знаходиться під значним впливом секторальної і кон- 
тентної трансформації, що зумовлена швидкими змінами глобального інформаційного середовища. Основними драйверами таких подібного роду зрушень виступають: процеси формування різнорівневих плат формових, економічних, соціальних і політичних інтересів, котрі виникають на основі колаборації технологічних трендів; таксомонічна дифузія регулювання медійного ринку спільноти, що містить у собі пряму та приховану підтримку виробника, який працює у важливому секторі спільних (для учасників проекту) інтересів; комерціалізація медійної індустрії та доступний для власників спосіб захисту авторських прав; зростаюча діджиталізація медійних технологій та посилена конкуренція в європейському інформаційному просторі просторі медійних компаній з США, але вже Китаю, з недавньогочасу - Російської Федерації та деяких арабських країн. Оцінювання тих фрундаментальних змін, що панують на європейському континенті неможливо прослідкувати без нового інструментарію, який дозволяє більш чітко, змістовно та системно оцінити процес модернізації ринку, котрий ще до недавнього часу вважався сталим і стабільним щодо власної структури, обсягів продуктів, що випускаються, контенту окремих проектів ічисленних інших трендів, що й зумовлювали прозорість $і$ прогностичність медійного ринку. Натомість зараз саме він потребує більш глибокого та грунтовного аналізу, а також використання нових ідентифікаційних підходів, які дозволятимуть суттєво підвищити ймовірність прогнозів європейського медійного ринку.

\section{Література:}

1. Sulehria F. Corruption in Consequence of Media Globalization. - New York: Routledge, 2018. - 258 p.

2. Fontaine G., Kevin D. Mavise extra. Media ownship: towards pan - European TV groups? - 2016, June: European Audiovisual Observatory. $-58 \mathrm{p}$.

3. Dunett P. The world television industry: An Economic Analysis. - London: Routledge, 2010. - 244 p.

4. Media in Europe. URL: www. marketresearch. com /markettine - v3883/ media - Europe 12881398 (дата звернення: 05.02.2020).

5. Rooke R. European Media in the Digital Age: Analysis and Approachess. - London: Routledge, 2013. - 288 p.

6. Harcout A. Europeanization as Couvergence: The Regulation of Media Markets in the European Union. Oxford: Oxford Scholaship Online, 2003. - 236 p.

7. Doukas D., Syrpis P. The EU Media Market and the interplay between the legislature and the Judiciary: /in The judiciary, the legislature and the EU internal Market. - Cambridge: Cambridge University Press, 2012. - P. 147-176.

8. О'Конор, І. Макдермотт. Системне мислення. Пошук неординарних рішень / Пер. з англ. Н. Сасюк. К.: Наш формат, 2018. - 240 c.

9. Deloitte. The future of the TV and video Landscape by 2030. Center for the Long view. - Deloitte, 2019. - P. 3-30.

10. International Television Expert Group URL: Режим доступу: www. international - television. org /tv_market_data /word - tv - market - 2010. Html (дата звернення: 05.02.2020)

11. Келлі К. Невідворотнє. 12 технологій, що фрормують наше майбутнє / Пер. з англ. Наталія Валевська. К.: Наш формат, 2018. - 304 с.
12. Audiovisual Media in Europe: localized, Targeting and language offers. Parts 2. Audiovisual media services targeting other countries. - Strasbourg: European Audiovisual Observatory, 2018. - 60 p.

13. Focus 2018. World Film market Trends. Strasbourg: European Audiovisual Observatory, 2018. $45 \mathrm{p}$.

14. Chuzhykov V. Comparative and analysis of regional dynamics of Ukraine and Georgia /Ed.by Dmytro Lukianenko, Teimuraz Beridze/In: Strategic priorities for developing Ukraint and Georgia: Innovation and partnership. - Batumi, 2018. - 308 p.

\section{References:}

1. Sulehria, F. (2018), Corruption in Consequence of Media Globalization, Routledge, New York, USA.

2. Fontaine, G. and Kevin, D. (2016), Mavise extra. Media ownship: towards pan - European TV groups?, European Audiovisual Observatory, Strasbourg, France.

3. Dunett, P. (2010), The world television industry: An Economic Analysis, Routledge, London, UK.

4. MarketResearch.com (2019), "Media in Europe", available at: www.marketresearch.com/markettinev3883/media-Europe12881398/(Accessed 05 February 2020).

5. Rooke, R. (2013), European Media in the Digital Age: Analysis and Approachess, Routledge, London, UK.

6. Harcout, A. (2003), Europeanization as Couvergence: The Regulation of Media Markets in the European Union, Oxford Scholaship Online, Oxford, UK.

7. Doukas, D. and Syrpis, P. (2012), The EU Media Market and the interplay between the legislature and the Judiciary in The judiciary, the legislature and the EU internal Market, Cambridge University Press, Cambridge, UK.

8. O'Konor, I. (2018), Systemne myslennia. Poshuk neordynarnykh rishen'[The Art of Systems Thinking: Essential Skills for Creativity and Problem Solving], Nash format, Kyiv, Ukraine.

9. Deloitte (2019), "The future of the TV and video Landscape by 2030, Center for the Long view, Deloitte, France.

10. International Television Expert Group (2019), available at: www.international-television.org/tv_market_data/word-tv-market-2010 Html (Accessed 05 February 2020).

11. Kelli, K. (2018), Nevidvorotnie. 12 tekhnolohij, scho formuiut' nashe majbutnie [The Inevitable: Understanding the 12 Technological Forces That Will Shape Our Future], Nash format, Kyiv, Ukraine

12. European Audiovisual Observatory (2018), Audiovisual Media in Europe: localized, Targeting and language offers. Parts 2. Audiovisual media services targeting other countries. European Audiovisual Observatory, Strasbourg, France.

13. European Audiovisual Observatory (2018), Focus 2018. World Film market Trends, European Audiovisual Observatory, Strasbourg, France.

14. Chuzhykov, V. (2018), "Comparative and analysis of regional dynamics of Ukraine and Georgia", Strategic priorities for developing Ukraine and Georgia: Innovation and partnership, Batumi, Georgia.

Cтаття надійшла до редакиї 20.02.2020 p. 